\title{
Increased production of tumor necrosis factor- $\alpha$ in whole blood cultures from children with primary malnutrition
}

Z.M.A. Azevedo ${ }^{1 *}$ R.A. Luz ${ }^{1 *}$, S.H. Victal', B. Kurdian ${ }^{1}$, V.M. Fonseca ${ }^{1}$, C. Fitting ${ }^{3}$, F.P. Câmara², N. Haeffner-Cavaillon ${ }^{4}$, J.-M. Cavaillon ${ }^{3}$, M.I.C. Gaspar Elsas ${ }^{1}$ and P. Xavier Elsas ${ }^{2}$

\author{
${ }^{1}$ Departamento de Pediatria e Laboratório de Fisiopatologia Humana, \\ Instituto Fernandes Figueira, FIOCRUZ, Rio de Janeiro, RJ, Brasil \\ Instituto de Microbiologia Professor Paulo de Góes, \\ Universidade Federal do Rio de Janeiro, Rio de Janeiro, RJ, Brasil \\ ${ }^{3}$ Unité Cytokines et Inflammation, Institut Pasteur de Paris, Paris, France \\ ${ }^{4}$ Département de l'Évaluation Scientifique de I'INSERM, Paris, France
}

\section{Correspondence \\ Z.M.A. Azevedo \\ Unidade de Terapia Intensiva \\ Departamento de Pediatria \\ Instituto Fernandes Figueira FIOCRUZ \\ Av. Rui Barbosa, 716 \\ 22250-020 Rio de Janeiro, RJ \\ Brasil \\ Fax: +55-21-2553-8094 \\ E-mail: zina@iff.fiocruz.br \\ zina_maria@uol.com.br \\ *These authors contributed equally to this research and should be considered to be joint first authors. \\ Research supported by PAPES/FIOCRUZ, INSERM (Réseau \\ Scientifique Nord-Sud), FINEP, FINEP/BID and PRONEX, and by fellowships from $\mathrm{CNPq}$ (to R.A. Luz) and RHAE (to \\ J.-M. Cavaillon).}

Received February 27, 2004 Accepted October 13, 2004

\begin{abstract}
Because low tumor necrosis factor- $\alpha$ (TNF- $\alpha$ ) production has been reported in malnourished children, in contrast with high production of TNF- $\alpha$ in experimental protein-energy malnutrition, we reevaluated the production of TNF- $\alpha$ in whole blood cultures from children with primary malnutrition free from infection, and in healthy sex- and agematched controls. Mononuclear cells in blood diluted 1:5 in endotoxin-free medium released TNF- $\alpha$ for $24 \mathrm{~h}$. Spontaneously released TNF- $\alpha$ levels (mean \pm SEM), as measured by enzyme immunoassay in the supernatants of unstimulated 24-h cultures, were 10,941 $\pm 2,591$ $\mathrm{pg} / \mathrm{ml}$ in children with malnutrition $(\mathrm{N}=11)$ and $533 \pm 267 \mathrm{pg} / \mathrm{ml}$ in controls $(\mathrm{N}=18)(\mathrm{P}<0.0001)$. TNF- $\alpha$ production was increased by stimulation with lipopolysaccharide (LPS), with maximal production of $67,341 \pm 16,580 \mathrm{pg} / \mathrm{ml}$ TNF- $\alpha$ in malnourished children and 25,198 $\pm 2,493 \mathrm{pg} / \mathrm{ml}$ in controls $(\mathrm{P}=0.002)$. In control subjects, LPS dosedependently induced TNF- $\alpha$ production, with maximal responses obtained at $2000 \mathrm{ng} / \mathrm{ml}$. In contrast, malnourished patients produced significantly more TNF- $\alpha$ with $0.02-200 \mathrm{ng} / \mathrm{ml}$ LPS, responded maximally at a 10 -fold lower LPS concentration $(200 \mathrm{ng} / \mathrm{ml})$, and presented high-dose inhibition at $2000 \mathrm{ng} / \mathrm{ml}$. TNF- $\alpha$ production a) was significantly influenced by LPS concentration in control subjects, but not in malnourished children, who responded strongly to very low LPS concentrations, and b) presented a significant, negative correlation ( $\mathrm{r}$ $=-0.703, P=0.023$ ) between spontaneous release and the LPS concentration that elicited maximal responses in malnourished patients. These findings indicate that malnourished children are not deficient in TNF- $\alpha$ production, and suggest that their cells are primed for increased TNF- $\alpha$ production.
\end{abstract}

Key words - TNF- $\alpha$

- Malnutrition

- LPS 


\section{Introduction}

Malnutrition is associated with abnormalities in the specific immune response and with increased susceptibility to infection $(1,2)$. However, pro-inflammatory cytokines, including tumor necrosis factor alpha (TNF$\alpha$ ), can also be produced by cells involved in natural immunity after exposure to many pathogenic microorganisms and their products $(3,4)$. This may occur in primary childhood malnutrition, which, far from being an isolated medical problem occurring in a controlled environment, is associated with increased environmental exposure to infectious hazards due to deficient sanitation, poor hygiene standards, crowded housing, and restricted access to medical care. Hence, if malnourished children remain capable of producing pro-inflammatory cytokines to any extent, TNF- $\alpha$ production induced by environmental pathogens and/or their products should be detectable in tissues or cells from these patients. The weight loss, negative nitrogen balance, skeletal muscle catabolism, and increased liver weight $(5,6)$ induced by TNF- $\alpha$ and IL- 1 may possibly add to the metabolic abnormalities of malnutrition.

Data from the literature do not provide a coherent picture. Several studies describe a marked deficit in TNF- $\alpha$, IL-1, and IL-6 production in severe childhood malnutrition (7-10) while others have reported that starvation increases TNF- $\alpha$ production (11). Furthermore, production of IL- 1 and IL- 6 is increased in malnourished subjects free from infection (12), and production of TNF- $\alpha$ and IL-1 proceeds normally in animal models of protein malnutrition $(13,14)$. Finally, increased levels of soluble TNF- $\alpha$ receptors, which are induced by sustained increases in TNF- $\alpha$ receptors as part of regulatory mechanisms (15-18), have been detected in malnourished children (19), suggesting that these children are capable of significant TNF$\alpha$ production.

These discrepancies may be partly due to differences in methodology, including: a) cytokine quantitation by immunoassays versus bioassays $(7,9)$; b) the measurement of cytokines released in the absence of known stimulation or induced by various agonists $(7,9)$; c) the use of non-comparable patient populations, especially if one considers the differences in the clinical presentation of malnutrition between geographically and ethnically distinct populations (20); d) the clinical and anthropometric criteria that define malnutrition $(7,9)$; e) the clinical and laboratory data used to exclude infection. Often, the study design lacks a control group of healthy children $(7,9)$ and dose-response relationships for the stimulus are not reported $(7,9)$, so that it is unclear how closely the data reflect the malnourished subjects' entire potential for cytokine production. Accordingly, we reassessed the production of TNF- $\alpha$, both "spontaneous" and induced by a wide range of concentrations of lipopolysaccharide (LPS), in Brazilian children with primary malnutrition as well as in a healthy control group. Every effort was made to exclude clinical or subclinical infection and parasitic infestation, which increase TNF- $\alpha$ production $(3,21)$. We report that large amounts of TNF- $\alpha$ are produced in whole blood cultures from malnourished children, both in the absence and in the presence of LPS.

\section{Material and Methods}

\section{Subjects}

With the approval by the Board of Ethics in Medical Research, FIOCRUZ, a study was conducted on malnourished children enrolled in a long-term project for nutritional assessment and recovery at the Centro de Saúde Germano Sinval Farias (CSGSF), FIOCRUZ, Rio de Janeiro. This governmentsupported health center provides primary care and specialty follow-up to a very poor community (Manguinhos and Mandala de 
Pedra shantytowns) with an average family income below US $\$ 80$ per month, due to high unemployment rates and a large proportion of broken homes. CSGSF carries out community work focused on social, nutritional and clinical aspects, and targeted on the children of the community. Children diagnosed as malnourished by the clinical staff of CSGSF are first referred to the malnutrition clinic for a complete nutritional and clinical evaluation, including a detailed nutritional history, anthropometric evaluation and a thorough physical examination by a senior pediatrician. The nutrition specialist in charge of the clinic holds monthly meetings with the mothers or legal representatives of the children, where the social and nutritional status of the patients is discussed and guidance is provided. The mothers of the children enrolled in the study were asked to sign an Informed Consent Form and to provide detailed information on social and economical history (family income, unemployment status, number of people per home, hygiene habits, sanitation structure, endemic and/or infectious hazards near the home), family history (family structure, number of siblings, death/disease of siblings, hereditary diseases), perinatal history (progress of pregnancy, birth and developmental history), immunological history (vaccinations, childhood infections), nutritional history (duration of breast-feeding, daily diet). Control (healthy) subjects were children referred to the Department of Surgery, Instituto Fernandes Figueira, also at FIOCRUZ, Rio de Janeiro, for elective surgery for phimosis or inguinal hernia. The control group was selected on the basis of the following considerations: a) the mothers of well-nourished children living in the same area as the malnourished children did not substantially adhere to the study, since they could detect no benefit in it for children they considered to be healthy, but perceived the requirements of the study (which included several lengthy consultations, parasitological treatment and blood sampling), as a major inconvenience, in contrast to the mothers of malnourished children, who were highly motivated, having already joined the project to seek help for children they perceived as sick, and b) in the elective surgery group, blood sampling for preoperative evaluation is mandatory, and since the surplus of these samples was used for the study, enrollment involved no additional procedure, being therefore easier to accept by the consenting parents. To completely rule out asymptomatic parasitic infections as a potential stimulus for TNF- $\alpha$ production, the children in both groups were empirically treated for parasitic infection with mebendazole and metronidazole 15 days before the laboratory tests.

\section{Nutritional assessment}

The anthropometric measurements used for nutritional assessment were weight, height, triceps skinfold thickness, and midupper arm circumference, and the following indices were calculated: weight/age, height/ age, and weight/height, using the Epi-Info Version 6.04 software, and database for growth curves of the National Center for Health Statistics, Centers for Disease Control, Atlanta, GA, USA. Values deviating from normal are statistically defined as those below - 2 standard deviations (SD) or Z score $<2.3$ rd percentile, or above $+2 \mathrm{SD}$ or Z score $>97.7$ th percentile relative to the median, in agreement with previous studies $(20,22)$. Nutritional assessment was based on weight/ age or height/age, depending on the age of the subject: up to age 2 years, the cut-off value for defining a child as malnourished or control was the 3rd percentile of the weight/ age curve; above age 2 years, the cut-off value was the 3rd percentile of the height/ age curve. Malnourished and control children were further quantitatively evaluated by the SD/Z score (falling below $-2 \mathrm{SD}$ for malnourished children and above -2 SD for controls). The complete description of mal- 
nourished and control children included the distribution of SD for the three indices (weight/age, height/age, weight/height), as recommended by the WHO $(22,23)$. From triceps skinfold thickness and mid-upper arm circumference measurements, we calculated the total upper arm area, upper arm muscle area and upper arm fat area. For these indices, the cut-off point was the 5th percentile of the reference population, which corresponds to a $\mathrm{Z}$ score $\leq 1.650$ (24-26). We excluded from the study all children presenting one or more of the following features: a history of prematurity, malnutrition secondary to cancer, tuberculosis, diabetes, AIDS or HIV infection, immunological diseases, or other causes, kwashiorkor, congenital malformations or genetic diseases, chronic use of anti-inflammatory drugs (both steroidal and nonsteroidal), special enteral (glutamine $/ \omega_{3}$ fatty acids) or parenteral nutrition, or infectious disease.

\section{Laboratory tests}

Children from both groups were tested for plasma triglycerides and cholesterol levels, total plasma protein and fractions, transferrin, total and differential blood cell counts, platelet counts, mean red blood cell diameter, volume, and hemoglobin content, urinalysis and parasitological examination of the stools, and TNF production. For whole blood cultures, heparinized blood (diluted 1:5 in endotoxin-tested medium) was cultured in 24-well polystyrene plates (Corning Corporation, Corning, NY, USA), as described by Warren et al. (27), $0.5 \mathrm{ml}$ per well in triplicate. Cultures were stimulated or not with LPS, $20 \mathrm{pg} / \mathrm{ml}-2000 \mathrm{ng} / \mathrm{ml}$, for $24 \mathrm{~h}$ at $37^{\circ} \mathrm{C}$, in the presence of $5 \% \mathrm{CO}_{2}$.

Supernatants were obtained by centrifugation at $450 \mathrm{~g}\left(10 \mathrm{~min}, 20^{\circ} \mathrm{C}\right)$, aliquoted into $0.3-\mathrm{ml}$ volumes, and stored at $-80^{\circ} \mathrm{C}$ before assay. Culture supernatants were assayed at 1:125 dilution for unstimulated cultures or at 1:500 dilution for LPS-stimulated cultures for TNF- $\alpha$ by enzyme immunoassay (Medgenix EASIATM kits, Bio Source Europe S.A., Zoning Industrial B-6220, Fleurus, Belgium). The minimal detectable concentration of these cytokines was $3 \mathrm{pg} /$ $\mathrm{ml}$. Absorbance was measured with a Sigma Diagnostics EIA Multi-well reader (Sigma, St. Louis, MO, USA) and cytokine concentrations were calculated by linear regression using calibration curves covering the 15$1000 \mathrm{pg} / \mathrm{ml}$ concentration range.

\section{Reagents}

For whole blood cultures, we used endotoxin-tested RPMI 1640 medium containing $\mathrm{NaHCO}_{3}$ but no L-glutamine (B-4800; BioWhittaker, Verviers, Belgium). A stock solution of phenol-extracted E. coli 055:B5 LPS (Difco Europe, Grenoble, Isère, France) was prepared by sonication in deionized water, sterilized by UV irradiation, aliquoted and stored at $-20^{\circ} \mathrm{C}$ until use; working dilutions of LPS were freshly prepared from frozen aliquots in RPMI medium. Sodium heparin (stock solution of $5000 \mathrm{IU} / \mathrm{ml}$ ) was from Cristália (São Paulo, SP, Brazil).

\section{Statistical analysis}

Statistical analysis was carried out with the Epi-Info software package (Epi-Info Version 6.04; Centers for Disease Control, Epidemiology Program Office, Atlanta, GA, USA), the Statistical Analysis System software package (SAS 6.03, SAS Institute, Cary, NC, USA) and the Systat version 5.04 (Systat Software Inc., Richmond, CA, USA). The $t$ test was used to assess the significance of differences a) in anthropometric and laboratory data between control and malnourished subjects under comparable conditions, i.e., in unstimulated cultures or at the same LPS concentration; b) between spontaneous release and stimulated release for each LPS dose within either group; c) between boys and girls within either group. To identify 
whether age was a statistically significant factor, subjects within each group were divided into two age classes (up to 2 years and more than 2 years) and the $t$-test was also applied. ANOVA with the Tukey HSD correction was used to determine the differences between cultures exposed to different LPS concentrations within each group. Pearson's correlation coefficient was calculated for all anthropometric measurements. The chi-square test was used to determine differences concerning categoric variables. For values below 5 in $2 \times 2$ tables, the $\mathrm{P}$ value from the Fisher exact test was used.

\section{Results}

The data reported here refer to a group of 11 malnourished children who met the stringent criteria for absence of infection, and a group of 18 control subjects. Table 1 presents the age and sex distribution of both groups. No differences in ethnic origin were detected between groups, both of which included black, white and mulatto children. As shown in Table 2, there was a significant positive correlation among the $\mathrm{Z}$ scores of all indices (with the single exception of upper arm muscle area), thereby supporting the use of the established indices weight/age and height/age to characterize both groups. For all the remaining positively correlated indices and measurements, differences between the two groups were significant for the average $\mathrm{Z}$ scores, as shown in Table 3. Taken together, these data show that the groups fulfilled the criteria for malnourished and control children, respectively, when any of a number of well-established indices and indicators was used.

There were no significant differences between groups regarding a) frequency of low birth weight $(<2.500 \mathrm{~g})$ children $(\mathrm{P}<$ 0.05 , Fisher exact test), b) average weight at birth ( $\mathrm{P}=0.051, t$-test $), \mathrm{c})$ time of weaning ( $\leq 6$ months; $\mathrm{P}<0.05$, Fisher exact test), $\mathrm{d}$ ) prevalence of anorexia $(\mathrm{P}<0.05$, Fisher exact test), and e) prevalence of hypertriglyceridemia $(\mathrm{P}<0.05$, Fisher exact test $)$. By contrast, there were highly significant differences regarding a) prevalence of anemia $(\mathrm{P}=$

Table 1. Age and sex distribution of the subjects in the malnourished and control groups.

\begin{tabular}{lccclcc}
\hline Patients & \multicolumn{3}{c}{ Age (months) } & & \multicolumn{2}{c}{ Sex } \\
\cline { 2 - 4 } \cline { 6 - 7 } & $\begin{array}{c}\text { Lower } \\
\text { age limit }\end{array}$ & $\begin{array}{c}\text { Median } \\
\text { age }\end{array}$ & $\begin{array}{c}\text { Upper } \\
\text { age limit }\end{array}$ & & Male & Female \\
\hline Malnourished & 2 & 56 & 127 & & $63.6 \%(7 / 11)$ & $36.4 \%(4 / 11)$ \\
Control & 2 & 23 & 42 & & $72.2 \%(13 / 18)$ & $27.8 \%(5 / 18)$
\end{tabular}

Table 2. Pearson's correlation coefficients for anthropometric measurements and indices.

\begin{tabular}{|c|c|c|c|}
\hline Indices & Pearson (r) & $P$ & N \\
\hline W/A and $H / A$ & 0.87 & 0.0001 & 29 \\
\hline W/A and W/H & 0.85 & 0.0001 & 28 \\
\hline W/A and TUA & 0.63 & 0.0001 & 22 \\
\hline W/A and UFA & 0.82 & 0.0001 & 22 \\
\hline W/A and MUAC & 0.78 & 0.0001 & 22 \\
\hline W/A and TST & 0.76 & 0.0001 & 22 \\
\hline W/A and UMA & 0.15 & 0.47 & 22 \\
\hline $\mathrm{H} / \mathrm{A}$ and $\mathrm{W} / \mathrm{H}$ & 0.66 & 0.0007 & 28 \\
\hline $\mathrm{H} / \mathrm{A}$ and TUA & 0.69 & 0.0004 & 22 \\
\hline $\mathrm{H} / \mathrm{A}$ and UFA & 0.63 & 0.001 & 22 \\
\hline $\mathrm{H} / \mathrm{A}$ and $\mathrm{MUAC}$ & 0.67 & 0.0006 & 22 \\
\hline H/A and TST & 0.52 & 0.012 & 22 \\
\hline H/A and UMA & 0.14 & 0.50 & 22 \\
\hline W/H and TUA & 0.76 & 0.0001 & 22 \\
\hline W/H and UFA & 0.84 & 0.0001 & 22 \\
\hline W/H and MUAC & 0.69 & 0.0004 & 22 \\
\hline W/H and TST & 0.84 & 0.0001 & 22 \\
\hline W/H and UMA & -0.01 & 0.96 & 22 \\
\hline UFA and TUA & 0.82 & 0.0001 & 22 \\
\hline UFA and MUAC & 0.79 & 0.0001 & 22 \\
\hline UFA and TST & 0.97 & 0.0001 & 22 \\
\hline UFA and UMA & -0.02 & 0.89 & 22 \\
\hline TUA and MUAC & 0.96 & 0.0001 & 22 \\
\hline TUA and TST & 0.72 & 0.0001 & 22 \\
\hline TUA and UMA & 0.36 & 0.097 & 22 \\
\hline MUAC and TST & 0.69 & 0.0003 & 22 \\
\hline MUAC and UMA & 0.38 & 0.07 & 22 \\
\hline TST and UMA & -0.15 & 0.47 & 22 \\
\hline
\end{tabular}

W/A = weight-for-age; $H / A=$ height-for-age; $W / H$ = weight-for-height; $M U A C=$ midupper arm circumference; TST = triceps skinfold thickness; TUA = total upper arm area; UMA = upper arm muscle area; UFA = upper arm fat area. 
0.0003 , Fisher exact test), b) frequency of ingestion of animal protein other than milk $(\mathrm{P}=0.001$, Fisher exact test $)$, and $\mathrm{c})$ average family income ( $\mathrm{P}=0.001, t$-test). Differences in family income were associated with differences in a number of specific objective indicators, such as the type of dwelling (brick houses or wooden shacks) and access to sewage, which was not available to most malnourished patients and their families. Taken together, these data indicate that the differences in anthropometric indices are unlikely to be due to differences in prenatal development, or to anorexia, but are consistent with restricted protein-calorie intake after birth.

\section{TNF- $\alpha$ production in unstimulated whole blood cultures}

As shown in Figure 1, control children secreted $553 \pm 267 \mathrm{pg} / \mathrm{ml}$ TNF- $\alpha$ (mean \pm SEM) into the supernatants of unstimulated cultures, whereas malnourished children secreted 10,941 $\pm 2,591 \mathrm{pg} / \mathrm{ml}$ TNF- $\alpha$ under the same conditions. The difference between these groups was statistically significant $(\mathrm{P}<$ $0.0001)$. These findings suggest that cells from malnourished children have already been primed for high TNF- $\alpha$ production in vivo, even without further in vitro exposure to LPS. We found a statistically significant inverse correlation between spontaneous release of TNF- $\alpha$ and the weight/age ( $r=$ $-0.44, \mathrm{P}=0.01, \mathrm{~N}=29)$ and height/age $(\mathrm{r}=$ $-0.52, \mathrm{P}=0.004, \mathrm{~N}=28$ ) indices when data from both groups were pooled. In contrast, there was no correlation within the malnourished group between plasma triglyceride levels and spontaneous release of TNF- $\alpha(\mathrm{r}=$ $0.05, \mathrm{P}>0.89, \mathrm{~N}=8)$. Concerning spontaneous release of TNF, no significant differences were observed a) between anorectic and non-anorectic subjects within the malnourished $(\mathrm{P}=0.60)$ or control group $(\mathrm{P}=$ $0.25), b)$ between subjects with or without anemia $(\mathrm{P}=0.64$ and $\mathrm{P}=0.63$, respectively), or c) between subjects with or without hypertriglyceridemia $(P=0.89$ and $\mathrm{P}=0.20)$.

\section{TNF- $\alpha$ production in whole blood cultures stimulated with LPS}

When whole blood cultures from malnourished or control children were established in the presence of different LPS concentrations, TNF- $\alpha$ production was increased in every case (see below). As shown in Figure 2, maximal TNF- $\alpha$ production was elicited in 15 of 18 control children by LPS at $2000 \mathrm{ng} / \mathrm{ml}$, the highest concentration tested. In contrast, only 4 of 11 malnourished subjects presented maximal TNF- $\alpha$ production responses to the same LPS concentration. In the remaining 7, maximal TNF- $\alpha$ production was elicited by LPS concentrations below $2000 \mathrm{ng} / \mathrm{ml}$, while this occurred for only 3 of the 18 control subjects. In this case, higher LPS concentrations partially inhibited TNF$\alpha$ production (see below). These results indicate that malnourished children are not deficient in their ability to respond to LPS, as suggested by other studies $(7,9,10)$, and further indicate that malnourished children have

\begin{tabular}{|c|c|c|c|c|c|c|c|c|}
\hline & W/A & $\mathrm{H} / \mathrm{A}$ & W/H & MUAC & TST & TUA & UMA & UFA \\
\hline Malnourished & $-2.40 \pm 0.10$ & $-2.17 \pm 0.16$ & $-1.49 \pm 0.138$ & $-1.76 \pm 0.25$ & $-0.6 \pm 0.12$ & $-1.55 \pm 0.20$ & $-1.07 \pm 0.24$ & $-0.97 \pm 0.11$ \\
\hline Control & $-0.11 \pm 0.28$ & $-0.057 \pm 0.10$ & $-0.090 \pm 0.272$ & $-0.70 \pm 0.26$ & $0.54 \pm 0.38$ & $-0.53 \pm 0.23$ & $-0.97 \pm 0.16$ & $0.22 \pm 0.29$ \\
\hline$P$ & 0.000009 & 0.000014 & 0.00091 & 0.021 & 0.016 & 0.007 & 0.94 & 0.0009 \\
\hline
\end{tabular}


increased sensitivity to lower LPS concentrations, a point discussed in more detail below (see dose-response relationships).

\section{Maximal TNF- $\alpha$ production in malnourished and healthy subjects}

As shown in Figure 3, the amount of TNF- $\alpha$ released in the presence of maximally stimulatory LPS concentrations varied from subject to subject in both groups (panel A, malnourished children, panel B, control subjects). Nevertheless, the addition of LPS increased TNF- $\alpha$ production relative to the unstimulated cultures in every case, and the maximal response of each subject is taken to be a measure of the subject's capacity to produce TNF- $\alpha$ in vitro.

As shown in Figure 4, for the control group the maximally stimulated TNF- $\alpha$ production was $25,198 \pm 2,493 \mathrm{pg} / \mathrm{ml}$ (mean \pm SEM, N = 18), while for malnourished children the corresponding values were 67,341 $\pm 16,580 \mathrm{pg} / \mathrm{ml}($ mean \pm SEM, $\mathrm{N}=11)$. The difference between these groups was statistically significant $(\mathrm{P}=0.002)$. As also shown in Figure 4, large differences persisted when background TNF- $\alpha$ secretion (from unstimulated cultures) was subtracted for each patient, thus allowing visualization of the LPSdependent secretion. The difference in maximally stimulated TNF- $\alpha$ release between these groups was still more than $23,000 \mathrm{pg} /$ $\mathrm{ml}$ after subtraction of spontaneous release. These data document that cells from malnourished subjects release larger amounts of TNF- $\alpha$ than those from healthy subjects when exposed to optimally stimulating LPS concentrations.

\section{Factors influencing TNF- $\alpha$ production}

We evaluated which identifiable factors had an effect on TNF- $\alpha$ production. No statistically significant effect of age or sex could be demonstrated within either group. Highly significant differences could be attributed to

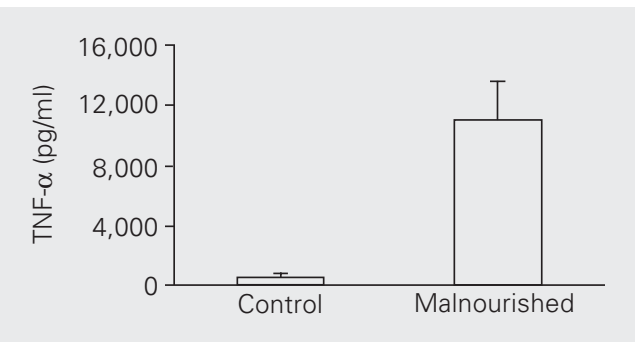

Figure 1. Tumor necrosis factor alpha (TNF- $\alpha$ ) production in unstimulated 24-h whole blood cultures of healthy controls ( $\mathrm{N}$ = 18) and malnourished children $(\mathrm{N}=11)$. Data are reported as mean \pm SEM of TNF- $\alpha$ measurements in 24-h culture supernatants. P between groups $<0.000$ (t-test).

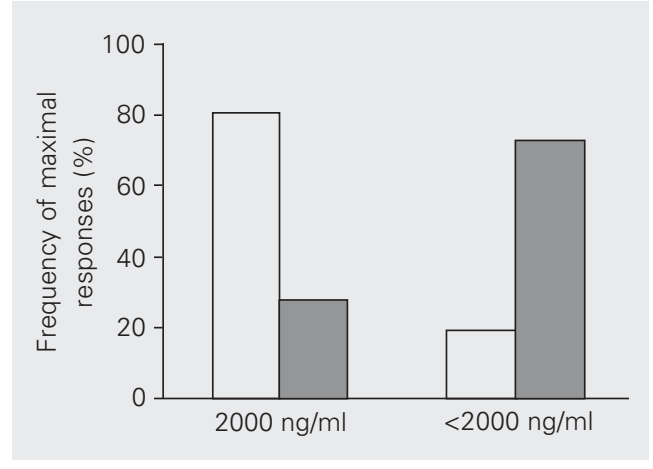

Figure 2. Induction of maximal tumor necrosis factor alpha (TNF- $\alpha$ ) production by maximal or submaximal LPS concentrations in 24-h whole blood cultures of healthy controls and malnourished children. Data are the \% of total subjects in each group presenting maximal TNF$\alpha$ production at the highest (2000 ng/ml) LPS concentration tested lopen columns, controls, $\mathrm{N}=18$; filled columns, malnourished subjects, $N=11$ ) or at lower $(0.002-200 \mathrm{ng} / \mathrm{ml})$ stimulus concentrations.

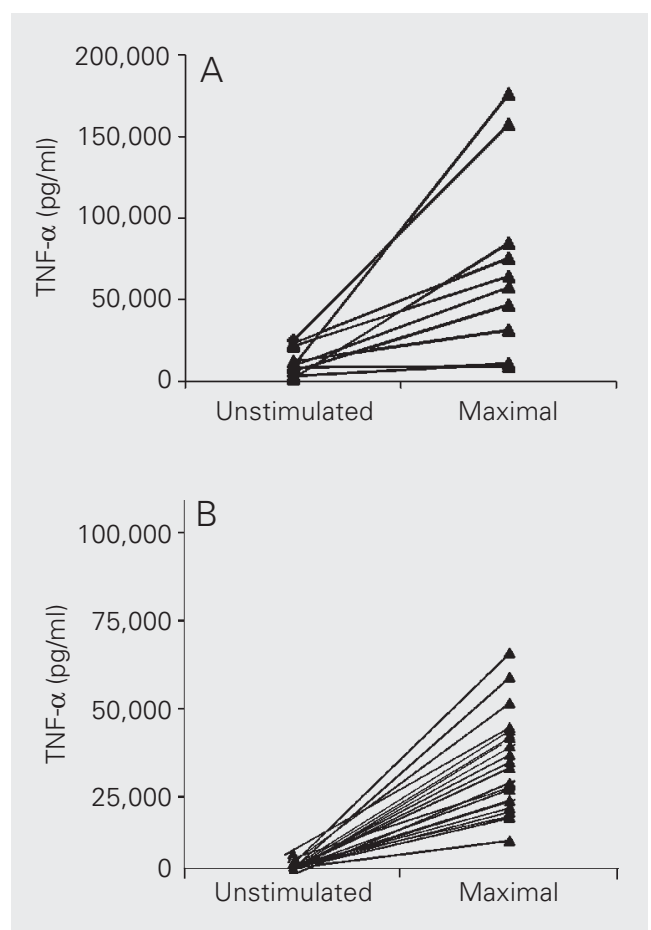

Figure 3. Ability of LPS to stimulate tumor necrosis factor alpha (TNF- $\alpha$ ) production in 24-h whole blood cultures of individual subjects. Data are TNF- $\alpha$ levels in 24-h whole blood cultures of malnourished children ( $A, N=11)$ and of healthy subjects $(B, N=18)$. Each line corresponds to a subject whose production in the absence (left) and in the presence of optimal doses of LPS (right) is indicated. 


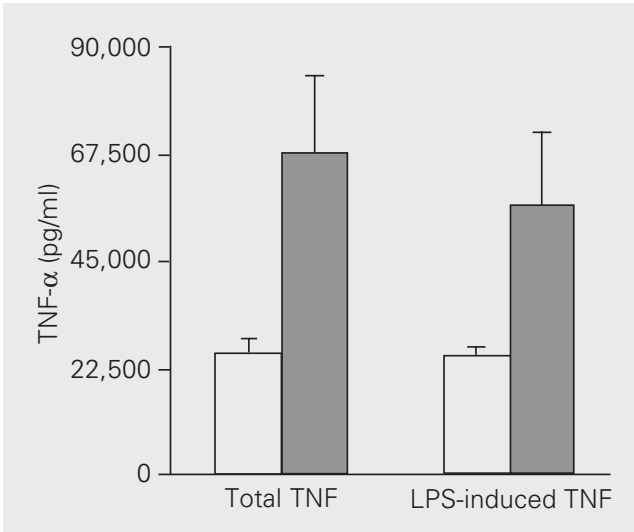

Figure 4. Tumor necrosis factor alpha (TNF- $\alpha$ ) production in maximally lipopolysaccharide (LPS)-stimulated whole blood cultures from healthy controls and malnourished children. Data are reported as mean \pm SEM for TNF- $\alpha$ in 24-h culture supernatants. Open columns, controls $(N=18)$; filled columns, malnourished subjects $(N=11)$. On the left, total TNF- $\alpha$ production in maximally stimulated cultures. On the right, TNF- $\alpha$ production after subtracting the background ("spontaneous") release for each patient. Differences between these groups were statistically significant $(P=0.002, t-$ test).

Table 4. Tumor necrosis factor alpha (TNF- $\alpha$ ) production in 24-h whole blood cultures and total and mononuclear leukocyte counts for the study subjects.

\begin{tabular}{|c|c|c|c|c|c|c|}
\hline Patients & $\begin{array}{c}\text { Age } \\
\text { (months) }\end{array}$ & $\begin{array}{l}\text { Leukocytes } \\
\qquad\left(/ \mathrm{mm}^{3}\right)\end{array}$ & $\begin{array}{l}\text { Lymphocytes } \\
\left(/ \mathrm{mm}^{3}\right)\end{array}$ & $\begin{array}{l}\text { Monocytes } \\
\left(/ \mathrm{mm}^{3}\right)\end{array}$ & $\begin{array}{l}\text { TNF- } \alpha \text { unstimulated } \\
\qquad(\mathrm{pg} / \mathrm{ml})\end{array}$ & $\begin{array}{c}\text { TNF- } \alpha \text { maximal } \\
(\mathrm{pg} / \mathrm{ml})\end{array}$ \\
\hline 1. Malnourished & 22.2 & 12000 & 5160 & 360 & 2630 & 84650 \\
\hline 2. Malnourished & 24.83 & 9100 & 3094 & 364 & 9235 & 57550 \\
\hline 3. Malnourished & 10.87 & 7200 & 4464 & 288 & 11995 & 31400 \\
\hline 4. Malnourished & 22.93 & 11800 & 4838 & 354 & 5975 & 46550 \\
\hline 5. Malnourished & 31.2 & 9600 & $1536^{*}$ & 384 & 23287 & 75500 \\
\hline 6. Malnourished & 18.26 & 13800 & 7038 & 552 & 21645 & 64250 \\
\hline 7. Malnourished & 42.34 & 12200 & 3904 & $732^{*}$ & 8975 & 176150 \\
\hline 8. Malnourished & 31.57 & 13600 & $2856 *$ & 408 & 8520 & 22700 \\
\hline 9. Malnourished & 2.365 & 11400 & 5928 & 570 & 24672 & 157525 \\
\hline 10. Malnourished & 12.02 & 15600 & 8268 & $936^{*}$ & 3299 & 10710 \\
\hline 11. Control & 53.84 & 12400 & 3968 & 124 & 235 & 37400 \\
\hline 12. Control & 75.82 & 6600 & 3432 & 396 & 4035 & 23050 \\
\hline 13. Control & 55.22 & 7000 & 2590 & 280 & 0 & 30550 \\
\hline 14. Control & 78.15 & 8500 & 3400 & 85 & 275 & 16150 \\
\hline 15. Control & 3.088 & 8900 & 6141 & 356 & 1505 & 44800 \\
\hline 16. Control & 98.94 & 5600 & 2296 & $504^{*}$ & 2715 & 38300 \\
\hline 17. Control & 50.26 & 11400 & 6156 & 342 & 0 & 7450 \\
\hline 18. Control & 127.1 & 7700 & 2387 & 308 & 0 & 35350 \\
\hline 19. Control & 60.74 & 7600 & 3040 & 304 & 0 & 13700 \\
\hline 20. Control & 65.8 & 8300 & 4731 & 249 & 0 & 15250 \\
\hline 21. Control & 121.3 & 6300 & 2016 & 315 & 0 & 18300 \\
\hline 22. Control & 42.73 & 10600 & 3604 & 636 & 0 & 21260 \\
\hline 23. Control & 68.85 & 7100 & 3550 & 284 & 1201 & 14045 \\
\hline 24. Control & 35.18 & 7000 & $2730 *$ & 70 & 0 & 35850 \\
\hline 25. Control & 73.55 & 13100 & 2227 & $524^{*}$ & 0 & 18300 \\
\hline 26. Control & 14.84 & 11500 & 5865 & 460 & 0 & 33140 \\
\hline 27. Control & 1.872 & 9600 & 5568 & 576 & 0 & 22020 \\
\hline 28. Control & 19.34 & 10100 & 5550 & 404 & 0 & 28655 \\
\hline 30. Malnourished & 11.89 & $20800^{*}$ & $13312^{*}$ & $1872^{*}$ & 117.5 & 19895 \\
\hline
\end{tabular}

Asterisks indicate counts outside the normal limits for the respective patient age interval, as defined by Ref. 30 
the presence of LPS over the entire concentration range tested when compared with unstimulated cultures within both groups. For control subjects, significant differences were also observed between cultures stimulated with different LPS concentrations. In contrast, such differences were not detected for malnourished children, which presented strong responses even at very low LPS concentrations (see below). We did not find a significant correlation between spontaneous release and maximal response in either group. However, we did find a significant negative correlation $(\mathrm{r}=-0.703, \mathrm{P}=0.023)$ between spontaneous release and the LPS concentration that induced maximal responses for malnourished (but not for control) subjects. Hence, malnourished children who presented a greater spontaneous release tended to respond maximally to lower LPS concentrations.

One important issue in this study refers to the relationship between the production of TNF- $\alpha$ by subjects from both groups and the number of cells present in peripheral blood, where mononuclear cells account for the bulk of TNF- $\alpha$ production $(28,29)$. Because total and differential cell counts were obtained for all subjects, we were able to rule out the possibility that differences in TNF- $\alpha$ production were due to different numbers of mononuclear cells in blood. As shown in Table 4, total leukocyte counts were within the normal range for the age of each subject in all cases (the normal limits for leukocytes, lymphocytes and monocytes for each age interval can be found in Ref. 30), with the exception of malnourished patient \#30. Patients \#5 and 8 (malnourished) and \#24 (control) presented lymphopenia; patients \#7 and 10 (malnourished) and \#16, 22 and 25 (controls) presented monocytosis. In all cases, lymphopenia or monocytosis was not severe enough to affect significantly total leukocyte counts. By contrast, patient \#30 (malnourished) had both lymphocytosis and monocytosis, which accounted for the leukocytosis.
Most importantly, there was no relationship between leukocyte, lymphocyte, monocyte, or mononuclear cell (lymphocytes plus monocytes) counts and increased TNF- $\alpha$ production, either spontaneous or LPS-induced. Highest TNF- $\alpha$ production was not associated with high leukocyte counts, either total or differential, and the only patient with leukocytosis had relatively low TNF- $\alpha$ production.

\section{Dose-response relationships}

As shown in Figure 5, when the ability of different LPS concentrations to elicit TNF- $\alpha$ production was analyzed, malnourished children, as a group, produced significantly more TNF- $\alpha$ than controls at all LPS concentrations, except $2000 \mathrm{ng} / \mathrm{ml}$. Significant differences were still found for 2, 20 and $200 \mathrm{ng} /$ $\mathrm{ml}$ LPS when background "spontaneous" release was subtracted for each patient $(\mathrm{P}=$ $0.013, \mathrm{P}=0.012$ and $\mathrm{P}=0.01$, respectively). For the control group, TNF- $\alpha$ production increased dose dependently with LPS concentration, with log increases in stimulus leading to approximately linear increases in production, and maximal production was observed at $2000 \mathrm{ng} / \mathrm{ml}$. In contrast, the doseresponse profile for the malnourished group was a more complex curve with a peak at 200 $\mathrm{ng} / \mathrm{ml}$. High-dose inhibition occurred for this group at $2000 \mathrm{ng} / \mathrm{ml}$ (the difference between output at $200 \mathrm{ng} / \mathrm{ml}$ and at $2000 \mathrm{ng} / \mathrm{ml}$ for malnourished children was significant, $\mathrm{P}<$ 0.001). Due to high dose inhibition in the malnourished group and to maximally stimulated production in control subjects, both

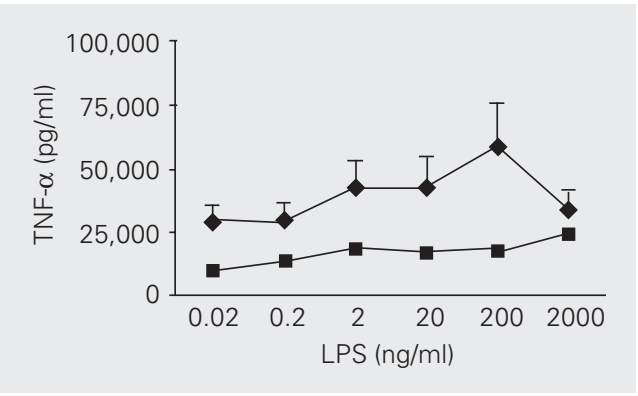

Figure 5. Dose-response relationships between tumor necrosis factor alpha (TNF- $\alpha$ ) production and lipopolysaccharide (LPS) stimulation in malnourished children and healthy controls. Data are reported as mean \pm SEM TNF- $\alpha$ measurements in 24-h culture supernatants. Squares, healthy controls $(N=$ 18); losenges, malnourished subjects $(N=11)$. Differences between the two groups were significant at all LPS concentrations except $2000 \mathrm{ng} / \mathrm{ml}$ (from 0.02 to $200 \mathrm{ng} / \mathrm{ml}$, P values were $\leq 0.001$, ANOVA with Tukey HSD correction). 
occurring at $2000 \mathrm{ng} / \mathrm{ml}$, this LPS concentration is the only one at which TNF- $\alpha$ production did not differ significantly between the two groups. These findings document that dose-response profiles covering a wide range of stimulus concentrations reveal differences that are undetectable when only single, maximal doses are used.

\section{Discussion}

Despite a substantial and sustained improvement in a number of health indicators beginning in the mid-70's, especially infant mortality and prevalence of infectious and parasitic diseases (31), malnutrition remains an important problem in Brazil. However, the presentation of malnutrition may differ significantly depending on the country and the time of study. For instance, the use of the weight/height index to diagnose malnutrition in South American children has been disputed on the basis of the low incidence of wasting in this population regardless of age (20). In malnutrition due to chronic and subacute environmental conditions, a decrease in the height/age indices is more sensitive than a change in weight/height, even in India, where changes in the latter indices are very conspicuous (22). Data from the present study confirm that the height/age index is a better parameter to be used to characterize malnutrition in Brazilian children. This indicates that malnutrition in today's Brazilian children is predominantly due to chronic restriction of protein-calorie intake, which has a major impact on linear growth, especially in the presence of repeated infectious episodes (32). This is consistent with the rarity of presentation of the classical pictures of marasmus and kwashiorkor in this population, in contrast to those described in other studies on cytokine production (7). On the other hand, our data failed to support the use of upper arm muscle area to evaluate malnutrition, since it is at variance with all the other anthropometric parameters used here, which are highly correlated in this population.

The laboratory parameter most closely associated with malnutrition in the present study was disturbed production of TNF- $\alpha$ in whole blood culture. TNF- $\alpha$ induces anorexia and cachexia in humans and in animal models. Even though TNF- $\alpha$ has a pathogenetic role in endotoxemia, autoimmunity and infection, its production is presumably beneficial to the host, because a) it is secreted by cells involved in natural immunity in response to a wide variety of microbial pathogens and products, b) it stimulates phagocytes and secretion of inflammatory mediators and cytokines, and c) it is required for resistance to some infections $(3,4,33,34)$. The evaluation of TNF- $\alpha$ production in malnourished children is important because a deficiency in TNF- $\alpha$ production may contribute to the immune deficits occurring in malnutrition; or, alternatively, excess production of TNF- $\alpha$, by inducing anorexia and cachexia, may aggravate the nutritional status. This type of analysis must be carried out by studying cumulative production in whole blood cultures $(27-29,35,36)$. This procedure avoids the complexities intrinsic to measurement of circulating TNF- $\alpha$, which arise from its short plasma half-life, its intermittent release from several tissues, and its in vivo binding to soluble TNF- $\alpha$ receptors, as well as from the need for extensive local production to reach important plasma concentrations. However, this type of study requires a comparison of malnourished subjects free of infection to normal control subjects who, apart from the nutritional status, closely resemble the study group.

Both "spontaneous" and LPS-induced TNF- $\alpha$ production in cultures from malnourished children were significantly increased relative to healthy controls. Increased production is associated with increased sensitivity to LPS as evidenced by a) the ability of submaximal LPS concentrations to elicit maximal TNF- $\alpha$ production in most mal- 
nourished children, but not in most healthy subjects (Figure 2), b) the induction of maximal TNF- $\alpha$ production in the malnourished group by LPS concentrations $1 / 10$ of those eliciting maximal production in the control group (Figure 5), and c) the statistically significant correlation between larger spontaneous release and maximal stimulation by lower LPS concentrations. Furthermore, the ability to respond more intensely to LPS was detectable in malnourished children over a large concentration range $(0.02-200 \mathrm{ng} / \mathrm{ml})$.

In both unstimulated and LPS-stimulated cultures, the absolute amounts of TNF- $\alpha$ secreted by cells from malnourished children were very high. In contrast, the amounts of TNF- $\alpha$ produced by cells from healthy control children in the absence of LPS stimulation were very close to the values reported for healthy adults (27) using identical conditions, as well as the conditions reported in a study using a similar whole blood culture system (28). This shows that our conditions for producing and measuring TNF- $\alpha$ are comparable to those of other studies employing the same technique in other countries. As an additional internal control, in the same assays from which the data reported here were derived we ran unrelated samples from other subjects (mostly septic patients), which yielded results strictly comparable to those reported in the literature (35). Finally, in a limited series of experiments, we measured bioactivity of samples from both malnourished and control children. The results (not reported here) were compatible with the amounts detected by ELISA in either group. It remains to be established, however, to what extent such intense TNF- $\alpha$ secretion by cells from malnourished subjects depends on specific features of the whole blood culture, such as the use of heparin (29) and dilution in culture medium (36), both of which have been reported to up-regulate TNF$\alpha$ production.

Taken together, the data presented here show that malnourished children are not de- ficient in TNF- $\alpha$ production in response to LPS, and actually produce this cytokine significantly more than normal subjects, both in the absence and in the presence of a wide range of LPS concentrations. The sensitivity to low doses of LPS was increased in malnourished children relative to healthy controls. While these findings are consistent with several lines of evidence from the literature (11-15), they are clearly at variance with those reported by other investigators addressing the same issue in other countries $(7,9)$. It is not clear, at present, whether these discrepancies can be reconciled without further studies, but methodological differences may play a major role. In the study by Doherty et al. (9), amounts of LPS as high as $10 \mu \mathrm{g} / \mathrm{ml}$ (five times our maximum LPS concentration) were used to elicit TNF- $\alpha$ production based on maximal stimulation of cytokine production by leukocytes in control samples. Assuming these came from normal subjects, Doherty et al. (9) may have missed the increased sensitivity of malnourished (but not of normal) children to low LPS concentrations. For our malnourished children, maximal TNF- $\alpha$ production occurred at 50 -fold lower LPS concentrations. It is conceivable that $10 \mu \mathrm{g} / \mathrm{ml}$ would cause high dose inhibition, since $2 \mu \mathrm{g} / \mathrm{ml}$ did so for $72 \%$ of our malnourished subjects. The study by Muñoz et al. (7) used mononuclear cells instead of whole blood. These investigators analyzed responses to $1 \mu \mathrm{g} / \mathrm{ml}$ LPS only, and may also have been working in a zone of high-dose inhibition for malnourished subjects. They did not observe spontaneous TNF- $\alpha$ release, suggesting that background cytokine production depends either on cells or on interactions present in whole blood, and is absent in isolated mononuclear cells. The patients studied by Muñoz et al. (7) resemble our own study group with respect to anthropometric indices, but not to laboratory values or age, their subjects being much younger, so that differences due to immaturity may have contributed to the lesser responses reported. On 
the other hand, direct comparison between the subjects studied by Doherty et al. (9) and ours is difficult since they used the Wellcome classification while we used the $\mathrm{Z}$ score, which is strongly recommended by the WHO $(22,23)$ and is being increasingly adopted because of its statistical soundness (37). A further factor may be the difference between wasting and stunting presentations, which differ in frequency among geographically and ethnically distinct populations (20).

In the present study, the presence of infectious and parasitic diseases, which favor TNF- $\alpha$ production, was ruled out on the basis of clinical and laboratory evaluation. Nevertheless, since increased "spontaneous" release of TNF- $\alpha$ in vitro as well as sensitization to low LPS concentrations were detected in malnourished subjects, it is possible that their blood cells had been primed in vivo by exposure to microbial products, such as endotoxin absorbed from the gut flora, as reported by others $(38,39)$. It is noteworthy, in this respect, that malnutrition is a risk factor for endotoxemia due to a combination of factors including bacterial superpopulation in the gut, atrophy of the gastrointestinal mucosa, altered luminal content of bile salts and free fatty acids, and abnormal clearance of absorbed endotoxin (38). One should keep in mind that these profiles reflect the potential for cytokine production by isolated cells in ex vivo culture (where nanogram amounts of TNF- $\alpha$ can accumulate, especially after exposure to a strong stimulus), but do not imply that such levels occur in vivo. Therefore, future studies should address the extent to which such priming results in increased levels of TNF- $\alpha$ in vivo, and what is the molecular mechanism of priming for increased synthesis ex vivo.

\section{Acknowledgments}

We are indebted to Dr. Paulo Boechat and the Department of Surgery, Institute Fernandes Figueira, FIOCRUZ, to Drs. Esther Zaborowski, Denise Barros, and Aurora Santos, and to Misses Selma Lima and Jalusy Almeida, CSGSF, FIOCRUZ, for access to patients and their families, expert assistance and laboratory studies.

\section{References}

1. Gross RL \& Newberne PM (1980). Role of nutrition in immunologic function. Physiological Reviews, 60: 188-302.

2. Zaman K, Baqui AH, Yunus M, Sack RB, Chowdhury HR \& Black RE (1997). Malnutrition, cell-mediated immune deficiency and acute upper respiratory infections in rural Bangladesh children. Acta Paediatrica, 86: 923-927.

3. Bazzoni F \& Beutler B (1996). The tumor necrosis factor ligand and receptor families. New England Journal of Medicine, 334: 17171725.

4. Allison A \& Eugui E (1995). Induction of cytokine formation by bacteria and their products. In: Brodgen KA, Roth JA, Stanton TB, Bolin CA, Minion FC \& Wannemuehler MJ (Editors), Virulence Mechanisms of Bacterial Pathogens. 2nd edn. American Society for Microbiology, Washington, DC, USA.

5. Ling PR, Schwartz JH \& Bistrian BR (1997). Mechanisms of host wasting induced by administration of cytokines in rats. American Journal of Physiology, 272: E333-E339.

6. Moldawer L, Andersson C, Gelin J \& Lundholm KG (1988). Regulation of food intake and hepatic protein synthesis by recombinant derived cytokines. American Journal of Physiology, 254: G450-
G456.

7. Muñoz C, Arévalo M, López M \& Schlesinger L (1994). Impaired interleukin-1 and tumor necrosis factor production in protein-calorie malnutrition. Nutrition Research, 14: 347-352.

8. Bhaskaram P \& Sivakumar B (1986). Interleukin-1 in malnutrition. Archives of Disease in Children, 61: 182-185.

9. Doherty JF, Golden MH, Remick DG \& Griffin GE (1994). Production and tumor necrosis factor-alpha in vitro is reduced in whole blood of severely malnourished children. Clinical Science, 86: 347-351.

10. Keenan RA, Moldawer LL, Yang RD, Kawamura I, Blackburn GL \& Bistrain BR (1982). An altered response by peripheral leukocytes to synthesize or release leukocyte endogenous mediator in critically ill, protein-malnourished patients. Journal of Laboratory and Clinical Medicine, 100: 844-857.

11. Vaisman N, Schattner A \& Hahn $T$ (1989). Tumor necrosis factor production during starvation. American Journal of Medicine, 87: 115.

12. Cederholm $T$, Wretlind $B$, Hellström $K$, Andersson $B$, Engström $L$, Brismar K, Scheynius A, Forslid J \& Palmblad J (1997). Enhanced generation of interleukins $1 \beta$ and 6 may contribute to the cachexia 
of chronic disease. American Journal of Clinical Nutrition, 65: 876882.

13. Bradley S, Vibhagool A, Kunkel SL \& Kauffman CA (1989). Monokine secretion in aging and protein malnutrition. Journal of Leukocyte Biology, 45: 510-514.

14. Skerret SJ, Henderson WR \& Martin TR (1990). Alveolar macrophage function in rats with severe protein calorie malnutrition. Arachidonic acid metabolism, cytokine release and antimicrobial activity. Journal of Immunology, 144: 1052-1061.

15. Sauerwein RW, Mulder JA, Mulder L, Lowe B, Peshu N, Demacker PNM, van der Meer JWM \& Marsh K (1997). Inflammatory mediators in children with protein-energy malnutrition. American Journal of Clinical Nutrition, 65: 1534-1539.

16. Van Zee KJ, Kohno T, Fischer E, Rock CS, Moldawer LL \& Lowry SF (1992). Tumor necrosis factor soluble receptors circulate during experimental and clinical inflammation and can protect against excessive tumor necrosis factor $\alpha$ in vitro and in vivo. Proceedings of the National Academy of Sciences, USA, 89: 4845-4849.

17. Spinas GA, Keller U \& Brockhaus M (1992). Release of soluble receptors for tumor necrosis factor (TNF) in relation to circulating TNF during experimental endotoxinemia. Journal of Clinical Investigation, 90: 533-536.

18. Shapiro L, Clark BD, Orencole SF, Poutsiaka DD, Granowitz EV \& Dinarello CA (1993). Detection of tumor necrosis factor soluble receptor p55 in blood samples from healthy and endotoxemic humans. Journal of Infectious Diseases, 16: 1344-1350.

19. Van Der Poll T, Jansen J, van Leenen D, von der Möhlen M, Levi M, ten Cate H, Gallati H, ten Cate JW \& van Deventer SJH (1992). Release of soluble receptors for tumor necrosis factor in clinical sepsis and experimental endotoxemia. Journal of Infectious Diseases, 168: 955-960.

20. Victora CG (1992). The association between wasting and stunting: an international perspective. Journal of Nutrition, 122: 1105-1110.

21. Scuderi P, Sterling KE, Lam KS, Ryan KJ, Ray CG, Peterson E, Slymen DJ \& Salmon SE (1986). Raised serum levels of tumor necrosis factor in parasitic infections. Lancet, 2: 1364-1366.

22. World Health Organization (1995). Physical status: the use and interpretation of anthropometry. WHO Technical Report Series, Geneva, Switzerland, 854-988.

23. World Health Organization (1986). Use and interpretation of anthropometric indicators of nutritional status. Bulletin of the World Health Organization, 64: 929-941.

24. Frisancho AR (1974). Triceps skin fold and upper arm muscle size norms for assessment of nutitional status. American Journal of Clinical Nutrition, 27: 1052-1058.

25. Frisancho AR (1981). New norms of upper limb fat and muscle areas for assessment of nutritional status. American Journal of Clinical Nutrition, 34: 2540-2545.

26. Frisancho AR (1990). Anthropometric Standards for the Assess- ment of Growth and Nutritional Status. The University of Michigan Press, Ann Arbor, MI, USA, 9-64.

27. Warren HS, Amato SF, Fitting C, Black KN, Loiselle PM, Paternack MS \& Cavaillon JM (1993). Assessment of ability of murine and human anti-lipid A monoclonal antibodies to bind and neutralize lipopolysaccharide. Journal of Experimental Medicine, 177: 89-97.

28. Wilson BM, Severn A, Rapson NT, Chana J \& Hopkins P (1991). A convenient human whole blood culture system for studying the regulation of tumor necrosis factor release by bacterial lipopolysaccharide. Journal of Immunological Methods, 139: 233-240.

29. Eggesbo JB, Hjermann I, Lund PK, Joo GB, Ovstebo R \& Kierulf $P$ (1994). LPS-induced release of IL-1ß, IL-6, IL-8, TNF- $\alpha$ and SCD14 in whole blood and PBMC from persons with high or low levels of HDL-lipoprotein. Cytokine, 6: 521-529.

30. Ebel BE \& Raffini L (2000). Hematology. In: Siperry GK \& lannone R (Editors), The Harriet Lane Handbook: A Manual for Pediatric House Officers. 15th edn. Mosby, St. Louis, MO, USA, 324-326.

31. Monteiro CA, Benício MHA \& Freitas ICM (1997). Melhoria em indicadores de saúde associados à pobreza no Brasil dos anos 90. Document obtained from the Internet at: [http://www.fsp.vsp.br/ nupens/],1-11. Accessed October, 1999.

32. Pesquisa Nacional sobre Demografia e Saúde (1996). Amamentação e Situação Nutricional de Mães e Crianças. Sociedade Civil BemEstar Familiar no Brasil (BEMFAM). Programa de Pesquisa de Demografia e Saúde (DHS). Macro-International Inc., DHS Program, Calverton, Huntingtown, MD, USA, 125-135.

33. Grell M (1996). Tumor necrosis factor (TNF) receptors in cellular signaling of soluble and membrane-expressed TNF. Journal of Inflammation, 47: 8-17

34. Douni E, Akassoglou K, Alexopoulou L et al. (1996). Transgenic and knockout analyses of the role of TNF in immune regulation and disease pathogenesis. Journal of Inflammation, 47: 27-38.

35. Ertel W, Kremer JP, Kenney J, Steckholzer U, Jarrar D, Trentz O \& Schildberg FW (1995). Downregulation of pro-inflammatory cytokine release in whole blood from septic patients. Blood, 85: 1341-1347.

36. Mitov IG, Kropec A, Benzing A, Just H, Garotta G, Galanos C \& Freundenberg M (1997). Differential cytokine production in stimulated blood cultures from intensive care patients with bacterial infections. Infection, 25: 206-212.

37. Sachdez HPS, Satyanarayana L, Kumar S \& Puri RK (1992). Classification of nutritional status as "Z score" or percent of reference median - does it alter mortality prediction in malnourished children? International Journal of Epidemiology, 21: 916-921.

38. Klein K, Fuchs GJ, Kulapongs P, Mertz G, Suskind RM \& Olson RE (1988). Endotoxemia in protein-energy malnutrition. Journal of Pediatric Gastroenterology and Nutrition, 7: 225-228.

39. Oberle MW, Graham GG \& Levin J (1974). Detection of endotoxaemia with the Limulus test: preliminary studies in severely malnourished children. Journal of Pediatrics, 85: 570-573. 